\title{
A long-term analysis of the declining population of the Egyptian vulture in the Italian peninsula: distribution, habitat preference, productivity and conservation implications
}

\author{
Fabio Liberatori ${ }^{a}$, Vincenzo Penteriani ${ }^{\mathrm{b}, *}$ \\ ${ }^{a} A L T U R A$ and Egyptian Vulture Project Italy, Via Igea 19/b, 00135Rome, Italy \\ bepartment of Applied Biology, Estación Biólogica de Doñana (EBD), C.S.I.C., Avda. de María Luisa s/n. \\ Pabellón del Perú, Apto de Correos, 1056, 41013 Sevilla, Spain
}

\begin{abstract}
Between the beginning of the 1970s and the early 1990s the breeding population of the Egyptian vulture (Neophron percnopterus) in the Italian peninsula declined from 29 to nine breeding pairs. We analysed the main aspects of the decline of this population during the last 30 years, namely: (1) landscape structure and composition of active and extinct nesting sites; (2) changes in the land use and number of cattle within the breeding range; (3) productivity (1986-1999) of the last nine pairs breeding in the Italian peninsula. Further decline in the breeding population was probably stopped by creating artificial feeding sites and protecting the last nesting sites from direct persecution. Nearly two-thirds of the pairs laid at least one egg per year, and half of the pairs fledged at least one young per year. The mean number of fledged young was $0.99 \mathrm{~T} 0.66$ per breeding pair, and $1.27 \mathrm{~T} 0.45$ per successful pair. About $75 \%$ of the breeding failures occurred during incubation, and $71 \%$ were related to human activities and direct persecution. The nesting cliff occupation rate, percentage of breeding attempts that fledged at least one chick and mean number of fledged young were negatively correlated with the distance to an artificial feeding site. \# 2001 Elsevier Science Ltd. All rights reserved.
\end{abstract}

Keywords: Egyptian vulture; Neophron percnopterus; Italy; Population decline; Landscape and number of cattle changes; Productivity; Conservation

\section{Introduction}

The Egyptian vulture (Neophron percnopterus) is a medium-sized scavenging bird of about $2 \mathrm{~kg}$. It mainly feeds on carrion of small vertebrates and scraps of meat from large carcasses where larger vultures are feeding, although it can sometimes attack live prey. It nests on cliffs, especially those surrounded by open and arid areas, where two eggs are laid early in the spring. This species has the largest range of all European vultures, breeding in mountain areas, plains and deserts around the Mediterranean Sea, Middle East, south-eastern exUSSR, Indian subcontinent, Sahel and eastern and southern Africa (Donazar, 1993). Egyptian vulture

\footnotetext{
*Corresponding author. Tel.: +34-954-23-23-40; fax: +34-954-6211-25.

E-mail addresses: liber.fab@iol.it (F. Liberatori), penteriani@ebd.csic.es (V. Penteriani).
}

populations have steadily declined over a large part of their European and African range during the twentieth century (Donazar, 1994) and still continue to decline throughout most of the species' European range (Elosegi, 1989; Donazar, 1994; Gallardo and Penteriani, 1999). The main factors driving this population change include: (1) human persecution, (2) habitat changes, and (3) modifications in traditional stock raising practices (Bologna, 1976; Garzon, 1977; Frier, 1978; Tico and Tico, 1984; Cortone and Liberatori, 1989; Liberatori and Cortone, 1992). Between 25 and $50 \%$ of the global breeding range of the Egyptian vulture lies within Europe, and $>90 \%$ of this population occurs in countries where a decline has been observed, mainly Bulgaria, France, Greece, Italy, Rumania, Spain and ex-Yugoslavia (Donazar, 1994; Gallardo and Penteriani, 1999). As a result, the Egyptian vulture is classified as an endangered species with an Unfavourable Conservation Status (Donazar, 1994). 
This paper examines changes in the Egyptian vulture population in the Italian peninsula during the last 30 years. Our main objectives were to: (1) report changes in population size and distribution between 1970-1999; (2) examine nesting habitat preferences; (3) determine breeding performance and success; (4) relate distribution and productivity to changes in landscape-use and numbers of cattle reared in the nesting areas.

\section{Study area and methods}

\subsection{Study area}

During the study (from 1984 to 1999) we censused all the historical nest sites of the Egyptian vulture in the Italian peninsula, as well as all the other potentially suitable cliff areas. It is possible to divide the Italian peninsula into three main breeding areas: the Ionian range (Calabria region) and the Gravine-Pollino range (Basilicata and Apulia range), both in southern Italy, and the Maremma range in central Italy (Tuscany and Latio range, along the Tyrrhenian Sea). The available historical information shows that the species used to be concentrated in central and southern Italy (Liberatori and Massa, 1992; Liberatori, 1993), probably because of environmental, climatic and migratory factors. Until the end of the nineteenth century, some pairs were still breeding on a narrow stretch of coast between the Maremma range and the Alps, the only northern area of the species distribution in the Italian peninsula, but they disappeared at the beginning of the twentieth century (Liberatori and Massa, 1992).

\subsection{Data collection}

The Egyptian vulture population of the Italian peninsula was systematically censused from 1984 to 1999. At the same time, we gathered information on the historical distribution and precise location of nest sites in the entire peninsula from the beginning of the 1970s. We classified a nest site as extinct when we no longer observed the presence of a pair or any attempt to reproduce (nuptial displays and egg laying). The term "nest site" is used to denote the cliff used by a reproductive pair in different years. Simultaneous occupation of neighbouring areas by different pairs, clarified any dubious cases of both extinct and active nest site, and allowed us to calculate the nearest neighbour distances (NNDs) between breeding pairs.

In the case of sites with only a single bird during the egg-laying period (from mid-April to early May), we continued to regularly check the site for possible late partner arrival and egg-laying. Nesting cliffs were censused by checking all the historical and potential reproductive sites from sea level to $1000 \mathrm{~m}$ a.s.l., the Italian peninsula upper limit (Liberatori and Massa, 1992). Censuses were always started in March, the main period of the settlement on territory after migration.

To collect data on productivity (from 1986 to 1999), each nest was visited at least three times in March, April and May. We avoided visiting nests from the egg-laying period to the first 2-3 weeks after hatching, the most critical period for reproduction. For this reason we could not collect detailed information on the date of egg-laying and hatching.

Following the terminology proposed by Steenhof (1987), a breeding pair was one that laid eggs, and a successful pair was one that fledged at least one young. Productivity was expressed as breeding success (percentage of nests which fledged at least one chick) and mean number of young fledged per breeding pair and per successful pair.

Analyses of the structure and composition of the landscape surrounding active and extinct nest sites were based on a $4 \mathrm{~km}$-radius circular plot centred on each nest (and a control plot). The latter was a randomly selected cliff, located in the $4 \mathrm{~km}$-radius plot. The radius of the plot corresponds to the mean distance travelled from the nest during a foraging trip of the species (Braillon, 1987; Ceballos and Donazar, 1988; Baumgart, 1991). Habitat composition and landscape structure within such circles were recorded on the basis of 1:25 000 land-use maps and 1:10 000 aerial photographs. Overall, we recorded 18 variables for the nest sites/control sites comparison, and 21 variables for the active nest sites/extinct nest sites comparison (Table 2): the recorded variables were the most commonly used ones in the analysis of the Egyptian vulture nesting habitat (Donazar et al., 1989). The information on changes in the land use and head of cattle for the period 1970-1990 were obtained from the periodical census of the National Statistics Institute (ISTAT, 1991) within the regions where nest sites were located. As this species feeds mainly on carcasses of small- and medium-sized animals, livestock carrion and rubbish (Donazar and Ceballos, 1988; Bergier and Cheylan, 1980; Elosegi, 1989), we considered cattle-rearing and rubbish dumps as additional elements in the analysis of the landscape surrounding the nesting cliff.

\subsection{Statistical analyses}

Nest site dispersion was analysed by means of the Gstatistic, calculated as the ratio between the geometric and the arithmetic mean of the squared NNDs; this index ranges from 0 to 1 , where values close to $1(>$ 0.65) indicate uniform distribution of nests (Brown, 1975). To analyse the choice of nesting site, we employed: (1) a discriminant function analysis (DFA) to test for differences in habitat structure and composition within a $4 \mathrm{~km}$-radius plot between active nest sites and 
Table 1

Decline of Egyptian vulture breeding pairs in the Italian peninsula during the period 1970-1990, and increase in nearest neighbour distances (NND)

\begin{tabular}{|c|c|c|c|}
\hline & 1970 & 1980 & 1990 \\
\hline \multicolumn{4}{|l|}{ Ionian range } \\
\hline Breeding sites & 12 & 9 & 7 \\
\hline Mean NND (m) & $7550 \mathrm{~T} 6110.3$ & 8916.7T 6199.9 & 6892.9T 5478.6 \\
\hline Range NND (m) & $750-17800$ & $2500-17800$ & $2500-17800$ \\
\hline G-value & 0.41 & 0.57 & 0.62 \\
\hline \multicolumn{4}{|c|}{ Gravine-Pollino range } \\
\hline Breeding sites & 11 & 7 & 6 \\
\hline Mean NND (m) & $22309.1 \mathrm{~T} 18907.5$ & $39557.1 \mathrm{~T} 40048.9$ & $45066.7 \mathrm{~T} 41900.1$ \\
\hline Range NNDs (m) & $2250-52000$ & $8300-123000$ & $8300-123000$ \\
\hline G-value & 0.38 & 0.44 & 0.44 \\
\hline \multicolumn{4}{|l|}{ Campania range } \\
\hline Breeding sites & 2 & 0 & 0 \\
\hline Mean NND (m) & 4000 T 0 & & \\
\hline \multicolumn{4}{|l|}{ Maremma range } \\
\hline Breeding sites & 4 & 2 & 0 \\
\hline Mean NND (m) & 13906.2 T 5785.6 & $17437.5 \mathrm{~T} 5568.5$ & \\
\hline Range (m) & $7250-21375$ & $13500-21375$ & \\
\hline G-value & 0.87 & & \\
\hline \multicolumn{4}{|l|}{ Total } \\
\hline Breeding sites & 29 & 18 & 13 \\
\hline Mean NND (m) & 13780.2 & 21779.2 & 24511.5 \\
\hline G-value & 0.63 & 0.65 & 0.25 \\
\hline
\end{tabular}

Table 2

Habitat preference variables of Egyptian vulture active nest site vs. control sites, and active vs. extinct nest site

\begin{tabular}{|c|c|c|c|}
\hline & Nest sites $(n=13)$ & Control sites $(n=10)$ & Extinct nest sites $(n=10)$ \\
\hline Nest height ${ }^{\mathrm{a}, \mathrm{b}}$ (lower layer) & 0 & - & 10 \\
\hline Nest height ${ }^{\mathrm{a}, \mathrm{b}}$ (central layer) & 46.1 & - & 50 \\
\hline Nest height ${ }^{\mathrm{a}, \mathrm{b}}$ (upper layer) & 53.9 & - & 40 \\
\hline$\%$ nest exposure (southern) ${ }^{\mathrm{b}}$ & 100 & - & 100 \\
\hline$\%$ nest exposure (northern) ${ }^{\mathrm{b}}$ & 0 & - & 0 \\
\hline$\%$ cliff exposure (southern) & 92.3 & 38.5 & 100 \\
\hline$\%$ cliff exposure (northern) & 7.7 & 61.5 & 0 \\
\hline Cliff elevation (m a.s.l.) & $318.5 \mathrm{~T} 139.1$ & $450.6 \mathrm{~T} 286.4$ & $303.6 \mathrm{~T} 96$ \\
\hline Cliff height $(\mathrm{m})$ & $135 \mathrm{~T} 125$ & $84.5 \mathrm{~T} 63.2$ & $97.8 \mathrm{~T} 120.2$ \\
\hline Cliff length (m) & $2542.3 \mathrm{~T} 3529.6$ & $2100 \mathrm{~T} 3545$ & 2515 T 3670.8 \\
\hline$\%$ of pasture & $34.1 \mathrm{~T} 8.6$ & $31.4 \mathrm{~T} 6.6$ & $40.3 \mathrm{~T} 13.7$ \\
\hline$\%$ of cultivation & $28.8 \mathrm{~T} 13.8$ & $28.6 \mathrm{~T} 15.2$ & $30.7 \mathrm{~T} 12.9$ \\
\hline$\%$ of forests & $26.7 \mathrm{~T} 14.3$ & $28.7 \mathrm{~T} 15.7$ & $21.9 \mathrm{~T} 12.1$ \\
\hline$\%$ of rock areas & $7.3 \mathrm{~T} 4.5$ & $7.9 \mathrm{~T} 5.2$ & $4.8 \mathrm{~T} 4.2$ \\
\hline$\%$ of urban development & $3.1 \mathrm{~T} 1.8$ & $3.4 \mathrm{~T} 2.7$ & $2.3 \mathrm{~T} 1.7$ \\
\hline Length of paved roadc $(\mathrm{km})$ & $41.8 \mathrm{~T} 29.2$ & $38.7 \mathrm{~T} 15.1$ & $21.9 \mathrm{~T} 12.5$ \\
\hline Number of rubbish dumps & $2.1 \mathrm{~T} 1.1$ & $2.1 \mathrm{~T} 1.1$ & $1 \mathrm{~T} 0.4$ \\
\hline Distance to the nearest breeding site $(\mathrm{m})$ & 24511.5 T 33746.8 & - & 17055 T 12299.2 \\
\hline Distance $^{\mathrm{d}}$ to rubbish dump $(\mathrm{m})$ & $5346.1 \mathrm{~T} 4486.2$ & $5586.1 \mathrm{~T} 4544.2$ & 5240T 2878.2 \\
\hline Distance to water $(\mathrm{m})$ & $752.7 \mathrm{~T} 800.1$ & $853.3 \mathrm{~T} 1079.9$ & 1019T 1140.8 \\
\hline Distance to built-up (m) & $2613.1 \mathrm{~T} 1489.5$ & 2930 T 2173.2 & $2655 \mathrm{~T} 1649.3$ \\
\hline Distance to isolated inhabited house (m) & $542.7 \mathrm{~T} 405.9$ & $546.9 \mathrm{~T} 427.2$ & $459.5 \mathrm{~T} 169.9$ \\
\hline Distance to paved road $(\mathrm{m})$ & $1015.4 \mathrm{~T} 787.7$ & $1161.5 \mathrm{~T} 852.8$ & $801 \mathrm{~T} 607.5$ \\
\hline Distance to dirt road $(\mathrm{m})$ & $260 \mathrm{~T} 169.6$ & $372.7 \mathrm{~T} 441.3$ & $359 \mathrm{~T} 231.5$ \\
\hline Distance to railway (m) & $8660.8 \mathrm{~T} 9071.4$ & $8575.4 \mathrm{~T} 9394.2$ & 7077.5T 3217.4 \\
\hline
\end{tabular}

a Calculated as a percentage, on a cliff divided into three layers (upper, central and lower).

b Variable identified by ordinal scores for the analysis.

c Calculated within a plot of $4 \mathrm{~km}$ of radius.

d All the distances are nearest distances. 

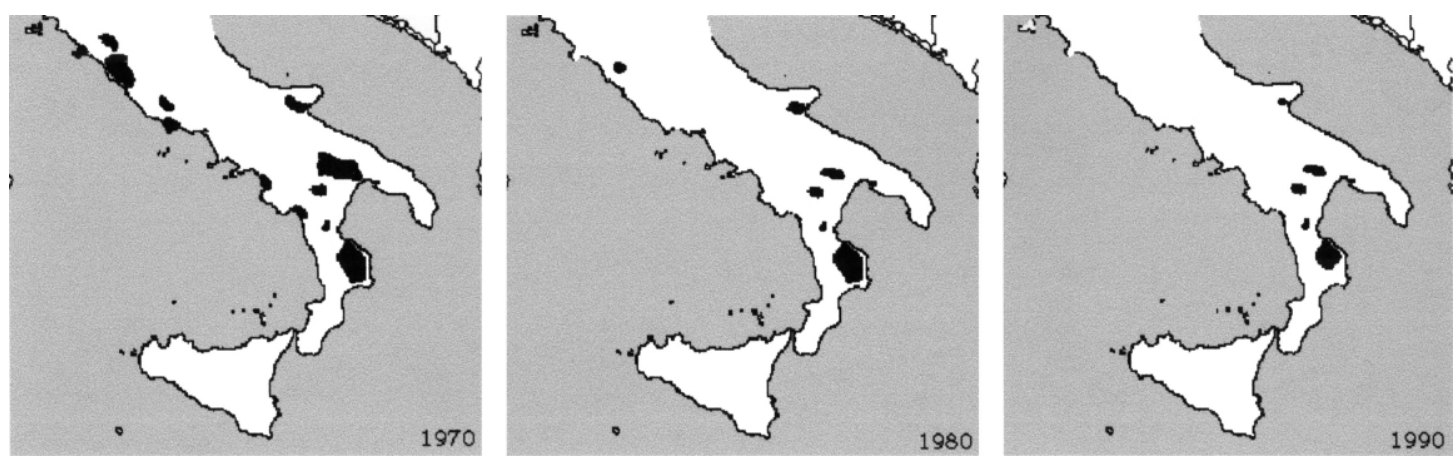

Fig. 1. Distribution of the Egyptian vulture breeding pairs in the Italian peninsula in the 1970s, 1980s and 1990s (from left to right).

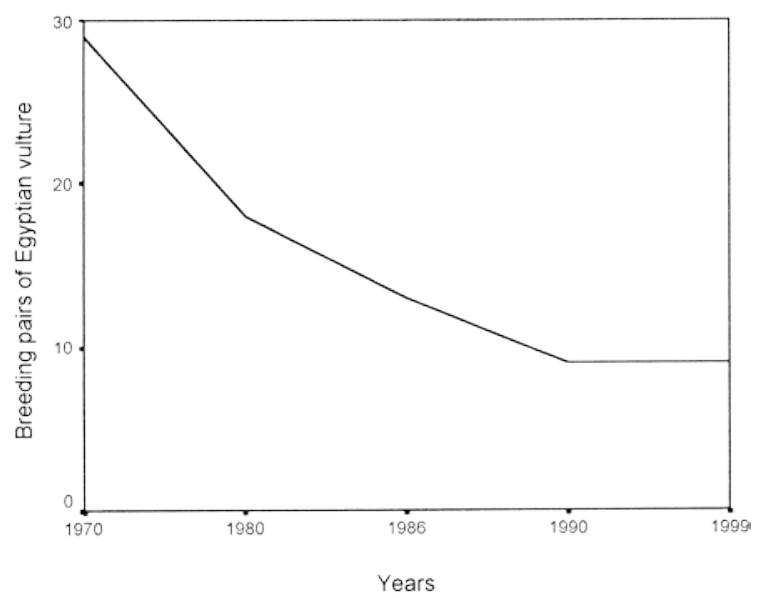

Fig. 2. Trend of the Italian peninsula breeding population of the Egyptian vulture during the period 1970-1999. The year 1990 represents the starting point of the application of the conservation measures.

(a) control sites, and (b) extinct nest sites; (2) a repeatedmeasures analysis of variance (ANOVA; Sokal and Rohlf, 1995) to test for modifications in landscape-use and cattle-rearing in the same nesting areas during the last three decades (1970s, 1980s, 1990s; ISTAT, 1991). A one-way ANOVA was used to point out differences in pair productivity from 1986 to 1999. We used nonparametric correlations to explore the associations between nest area occupancy, productivity, landscapeuse and structure, and presence of artificial feeding sites. Where data were not normally distributed, they were $\log _{e}$ transformed and square-root transformed as necessary (Sokal and Rohlf, 1981). All tests are twotailed and statistical significance was set at $\alpha=0.05$. Values presented are means T S.D.

\section{Results}

\subsection{Demographic change and breeding pair dispersion}

At the beginning of the 1970s, 29 breeding sites were distributed quite uniformly within four sectors of central and southern Italy (Table 1; Figs. 1 and 2): the Ionian (12 breeding sites), the Gravine-Pollino (11 breeding sites), the Campania region (two breeding sites), and the Maremma (four breeding sites). At the beginning of the 1980s, the reproductive population decreased to 18 breeding sites, but again, it showed quite a uniform distribution in three sectors of central and southern Italy (Table 1; Figs. 1 and 2): the Ionian (nine breeding sites), the Gravine-Pollino (seven breeding sites), and the Maremma (two breeding sites). At the end of the 1980s, the reproductive population decreased again to 13 breeding sites, characterised by a heterogeneous distribution in two sectors of southern Italy only (Table 1): the Ionian (seven breeding sites) and the Gravine-Pollino (six breeding sites). Since the early 1990s the breeding population seems to have stabilised at nine pairs (Figs. 1 and 2). The NND did not vary significantly during the three decades (ANOVA, $\mathrm{F}_{2,57}=1.13, \mathrm{P}=0.33$ ).

\subsection{Nest site preferences}

DFA showed significant differences $(\mathrm{P}<0.05)$ between active nest sites $(n=13)$ and control ones $(n=13)$ in four variables related to cliff characteristics (Table 2): exposure (exclusive selection of southerly exposed cliffs), elevation, height and length (values of these variables were higher at nest sites). The model correctly classified 10 Egyptian vulture nest sites $(76.9 \%)$ and 11 control sites $(84.6 \%)$. This classification was non random $\left(c^{2}=11.55\right.$, d.f. $=4, P=0.02$ ), and $80.8 \%$ of the overall plots were correctly classified. The DFA comparing active and extinct $(n=10)$ nest sites, showed significant differences $(\mathrm{P}<0.05)$ for 10 variables (Table 2$)$ : the values of cliff elevation, length of the nesting cliff, distance to railway lines, percentage of forests and rock areas, number of rubbish dumps and length of paved roads were higher in the active nest sites, whereas the values of distance to nearest water and built-up areas, as well as percentage of pastures, were higher in the extinct nest sites. All 13 of the Egyptian vulture nest sites and all 10 of the control sites were correctly classified by the model. 


\subsection{Changes in land use}

The only land use that changed significantly through the years was pasture in which the mean area progressively decreased from 76173 to 54168 ha, and was positively correlated with the number of active nest sites $\left(r_{s}=0.36, n=36, P=0.03\right)$. No significant differences were found in the amount of cultivated land, forests or numbers of cattle.

\subsection{Phenology and productivity}

A few pairs arrived in February but most came in March (Liberatori and Massa, 1992). The arrival of male and female partners was frequently asynchronous, and sometimes spanned several weeks. Egg-laying took place between 10 and 20 April, the latest date was the 21 May.

During the last 14 years of our study, the mean number of pairs that laid at least one egg in the Italian peninsula was $5.9 \mathrm{~T} 1.2(\mathrm{n}=126)$ per year $(65.1 \%$ of the overall breeding pairs) and the mean number of pairs which fledged at least one young was $4.4 \mathrm{~T} 1.4(49.2 \%$ of the overall breeding pairs). The mean number of young fledged per breeding pair was $0.99 \mathrm{~T} 0.66$, with no significant differences between years $\left(\mathrm{F}_{13,67}=1.04, \mathrm{P}=0.42\right)$. The mean number of young fledged per successful pair was $1.27 \mathrm{~T} 0.45$, with no significant differences between years $\left(\mathrm{F}_{13,48}=0.86, \mathrm{P}=0.59\right)$. Out of a total of 62 successful reproductions, 45 pairs fledged one young (72.6\%), and 17 fledged two young $(27.4 \%)$. The frequency of two fledged young was significantly negatively correlated with the distance from an artificial feeding site $\left(\mathrm{r}_{\mathrm{s}}=-0.86, \mathrm{n}=9, \mathrm{P}=0.003\right)$. The mean number of fledged young per year on the Italian peninsula was $5.6 \mathrm{~T} 2.1$, and the total number of young fledged over the 1988-1999 period was $79(n=126)$.

\subsection{Factors affecting productivity}

Between 1970 and 1999, we recorded 49 breeding failures, of which 37 occurred during incubation (75.5\%; Table 3) and the other 12 during the fledging period. Seventy-one percent of the causes of nest failure were related to humans, namely removal of eggs and

Table 3

Causes of breeding failure of Egyptian vulture pairs in the Italian peninsula (1970-1999): number of cases and percentages

\begin{tabular}{lrl}
\hline Cause of breeding failure & Incubation & Fledging \\
\hline Shooting & $17(34.7 \%)$ & \multicolumn{1}{l}{-} \\
Sterile eggs & $13(26.5 \%)$ & \multicolumn{1}{l}{-} \\
Robbery of eggs/young & $3(6.2 \%)$ & $10(20.4 \%)$ \\
Human disturbance near the nest site & $4(8.2 \%)$ & - \\
Poisoning & & $2(4 \%)$ \\
Total & $37(75.5 \%)$ & $12(24.5 \%)$ \\
\hline
\end{tabular}

young from the nest and shooting and poisoning of young and adults (Table 3 ). In one case, the proximate cause of nest failure was egg predation by a raven (Corvus corax): human activities near the nest caused the female to fly from the nest and the eggs were left defenceless for a long time. In the nine active nest sites checked from 1986 to 1999, the nest cliffs were always occupied by at least one bird, but not always by a breeding pair. The frequency of occupation by a reproductive pair over the 14 years was positively correlated with the mean number of fledged young for that territory $\left(\mathrm{r}_{\mathrm{s}}=0.88, \mathrm{n}=9, \mathrm{P}=0.002\right)$ and with the percentage of breeding attempts that fledged at least one chick $\left(r_{s}=0.94, n=9, P=0.0001\right.$; Table 4), and negatively correlated with the distance to an artificial feeding site $\left(\mathrm{r}_{\mathrm{s}}=-0.69, \mathrm{n}=9, \mathrm{P}=0.04\right)$. The percentage of breeding attempts that fledged at least one chick $\left(r_{s}=-0.69\right.$, $\mathrm{n}=9, \mathrm{P}=0.04$ ) and the mean number of fledged young were significantly negatively correlated with the distance to the nearest artificial feeding point $\left(\mathrm{r}_{\mathrm{s}}=-0.71, \mathrm{n}=9\right.$, $\mathrm{P}=0.03$ ). There was no significant correlation between either the mean number of fledged young, or the percentage of breeding attempts that fledged at least one chick and with the distance and number of rubbish dumps ( $\mathrm{P}=0.33$ to 0.7$)$.

\section{Discussion}

\subsection{Demographic trend and breeding pair dispersion}

Historical information, the negative trend in numbers of breeding pairs, and our 14 year-long monitoring of the population showed a serious decline of the species in the Italian peninsula. In about 30 years, starting from an effective population of 29 breeding pairs quite uniformly distributed in the centre and the south of the country, we observed a decrease of more than two-thirds of the reproductive population down to the current number of only nine pairs scattered around two areas of southern Italy. The relatively great distances between breeding sites, higher than the NNDs of other European populations (Table 5), further testify to the decline of the Egyptian vulture in Italy, especially when they are compared with the NNDs characterising the breeding population in the 1970s and 1980s. The decrease in the NNDs during the last 30 years seems not to be significant. This is probably due to the already relatively scattered distribution of the species in Italy, the density of which was decreasing in the early 1970s: the mean NND was lower than today, but several sites were already far away from each other. It is noteworthy that the population decline ceased early in 1990; probably as a result of actions to preserve these last nesting sites from direct persecution (e.g. nest protection, awakening of public opinion) and with the creation of artificial feeding sites. 
Table 4

Productivity of the Italian Egyptian vulture population in relation to the occupation frequency of the nest cliff (1986-1999)

\begin{tabular}{lllll}
\hline Occupation frequency $^{\mathrm{a}}$ & Nest sites & Fledged young & \% Successful nests & \% Nests failed in incubation \\
\hline $0-25 \%$ & 2 & $0.54 \mathrm{~T} 0.73$ & 4 & 67 \\
$26-50 \%$ & 0 & - & - & - \\
$51-75 \%$ & 3 & $0.45 \mathrm{~T} 0.55$ & 43 & 33 \\
$76-100 \%$ & 4 & $1.05 \mathrm{~T} 0.72$ & 77 & 16 \\
\hline
\end{tabular}

a Percentage of years in which the territory was occupied.

Table 5

Nearest neighbour distances (NNDs) and productivity of some European Egyptian vulture populations during the last 30 years

\begin{tabular}{|c|c|c|c|c|}
\hline Study area (source) & $\mathrm{NND}^{\mathrm{a}}$ & $\%$ Successful nests ${ }^{\mathrm{b}}$ & Number of breeding pair & Fledged young per successful pair \\
\hline \multicolumn{5}{|l|}{ Bulgaria } \\
\hline (Baumgart, 1991) & $\begin{array}{c}2750 \\
(\min : 600)\end{array}$ & - & - & $1.5(24)$ \\
\hline France & & & & \\
\hline $\begin{array}{l}\text { Provence (Luberon) } \\
\text { (Gallardo et al., 1987) }\end{array}$ & - & $96.5 \times(58)$ & $1.3(58)$ & $1.3(56)$ \\
\hline $\begin{array}{l}\text { Provence } \\
\text { (Bergier and Cheylan, 1980; Bergier, 1985) }\end{array}$ & - & $92(100)$ & $1(42)$ & $1.4(45)$ \\
\hline Pyrenean chain & 6830 & & & \\
\hline (Braillon, 1979, 1987) & $(800-49000)$ & $77(37)$ & $1.1(117)$ & $1.3(27)$ \\
\hline $\begin{array}{l}\text { Portugal } \\
\text { (Vasconcelos, 1987) } \\
\text { Spain }\end{array}$ & - & $86(14)$ & & $1.4(12)$ \\
\hline $\begin{array}{l}\text { Catalonia } \\
\text { (Marco and Garcia, 1981) }\end{array}$ & $\begin{array}{r}7000 \\
(1250-10500)\end{array}$ & - & - & $1.5(8)$ \\
\hline $\begin{array}{l}\text { Navarra } \\
\text { (Donazar and Ceballos, 1988) } \\
\text { USSR }\end{array}$ & - & $76(55)$ & $0.8(117)$ & $1.3(79)$ \\
\hline $\begin{array}{l}\text { (Abuladze and Shergalin, 1998) } \\
\text { Italy }\end{array}$ & - & $74.1(83)$ & $1.1(83)$ & $0.8(83)$ \\
\hline Present study & $\begin{array}{c}24511 \\
(2500-123000)\end{array}$ & $49.2(126)$ & $1(126)$ & $1.3(62)$ \\
\hline
\end{tabular}

a Calculated in metres.

b When possible, the $\mathrm{n}$ is specified in brackets.

\subsection{Nest site preference, land use and breeding changes}

The elements that seem to guide the selection of a nest site are linked to the characteristics of the cliffs, and less so to the landscape features we considered in the analysis. The importance of the cliff in the nest site selection process by this species was also showed by Donazar et al. (1989). In our study area, the species showed a strong preference for higher sections of south-facing cliffs, a preference typical of this species (e.g. Canut et al. 1988; Grubac, 1989; Carlon, 1992; Mundy et al., 1992; Vlachos et al. 1998). Compared with the control cliffs, both active and extinct nesting ones were higher and longer. This trend could be explained by the high persecution that affected the species in the twentieth century, which would have favoured individuals nesting in the higher, and thus most inaccessible, cliffs.

The significant decrease from 1970 to 1990 in the overall amount of open pasture land is correlated with the number of breeding sites. The fact that no significant difference was detected in the number of cattle between the period 1970-1990 shows that it is not the number of stock that is important for the species but the type and practice of cattle-rearing. The retraction of the breeding range of the species has been frequently linked to the reduction of traditional practices of cattle-raising (Muntaner and C.R.P.R., 1985; Simenon and Cheylan, 1985; Elosegi, 1989; Levy, 1990; Carrillo and Delgado, 1991; Carrillo and Delgado, 1991). For instance, in southern France, when transhumance disappeared early in the twentieth century, the decrease in the amount of carrion produced a contraction of $200 \mathrm{~km}$ south and $130 \mathrm{~km}$ west in the range of the local Egyptian vulture population (Bergier and Cheylan, 1980). Similar trends were shown in the Pyrenean chain (Braillon, 1979; Canut et al., 1988) and all over Spain (Perea et al., 1991a, b).

There were more active nest sites near rubbish dumps, probably because the recent decrease and changes in 
stock raising made rubbish dumps more important as a food resource, and cliffs near them might be preferred.

\subsection{Productivity}

The productivity of Egyptian vultures in the Italian peninsula is similar to that in some other European areas (southern France, northern Spain, Portugal, and Bulgaria; Table 5), although the percentage of successful nests is the lowest ever found in Europe. The significant correlation between the frequency of cliff occupation, productivity, frequency of two fledglings in the nest, and distance to an artificial feeding site may suggest that food availability is one of the most important elements affecting productivity and nest site quality. The relationship between occupation rate and productivity could be due to the interaction between habitat and bird quality, the most productive individuals occupying the best nest sites and vice versa (Newton, 1989). As pointed out for other raptors (Sergio and Bogliani, 1999), we can hypothesise that Egyptian vultures may recognise such a variation in site quality, and respond by settling in high-quality territories. Such a pattern of settlement is in accordance with the ideal despotic model of bird distribution (Fretwell and Lucas, 1970). The current number of breeding pairs, however, is too low and scattered really to prevent the occupancy of all the high-quality sites, and the four or five regularly occupied cliffs cannot be considered the only high-quality sites in southern Italy. For these reasons we suppose that the occupation of low quality sites may be due to old individuals (with lower reproductive success), or young individuals coming back to their natal territory (Newton, 1979). Moreover, human impact on the species is high and unpredictable and may affect productivity even in high quality sites, as in eastern Georgia (Abuladze and Shergalin, 1998).

Donazar and Ceballos (1988) observed that the younger of two chicks shows quite a slow growth in weight, tarsus length and feather development, and they hypothesised that the reproduction strategy of the species is to tend to have a single chick when the availability of food is low. The correlation between the frequency of two fledglings in the nest and the distance to an artificial feeding site seems to support this hypothesis.

\subsection{Conservation implications}

Two main points concerning the conservation of the Egyptian vulture stand out from our data. First, direct persecution (mainly hunting and poisoning) has been the main reason for its decline in Europe (Bijleveld, 1974), and although it has been recently reduced, direct persecution still occurs in some parts of France, Greece, Spain and Italy (Donazar, 1994; this study): over 70\% of the causes of failure were through intentional human persecution (Table 3). Moreover, when persecution was reduced by site protection, the Italian population ceased to decline. Secondly, food availability is a limiting factor that influences density, nest area occupancy and productivity of breeding pairs. The conservation strategy of the species should be concentrated on protecting the most productive sites by nest guarding, the widespread awakening of public opinion, and the creation of artificial feeding sites near those sites, as in other areas of Europe (Terrasse, 1985; Gallardo et al., 1987; Ceballos and Donazar, 1988; Liberatori and Cortone, 1991) and the Middle East (Levy and Mendelssohn, 1989; Levy, 1990, 1991). Artificial feeding points need to be active from the period of first arrivals from Africa so as to induce the pairs to settle locally (Meretsky, 1995; Meretsky and Mannan, 1999). For instance, the actual population of the Egyptian vulture in Provence (southern France) is essentially the result of the creation of artificial feeding sites in the Luberon massif. Since 1985, and after the population decrease of more than $75 \%$ (Gallardo et al., 1987; Gallardo and Penteriani, 1999), the presence of artificial feeding points allowed the population to increase, whereas it kept declining in the overall neighbouring areas (Gallardo, personal communication).

Efforts should be directed at identifying potentially high-quality nest sites (and if possible the factors that make these sites of higher quality than other ones) and protecting them. We think that the decline and threats of this Italian population are typical of the whole European landscape, and the conservation measures we adopted in Italy may be effective for the conservation of this small vulture in other areas of Europe too.

Endangered species often exist in isolated populations among which exchange of individuals may be quite infrequent, and they appear to have some of the characteristics of a metapopulation (McCullough, 1996). This stage may be a step on the way to loss of these populations and eventual local extinction of the species. If further decline can be stopped, as for the species in the Italian peninsula, such species may form a metapopulation in which there is extinction of some nesting territories and recolonisation from others. On the other hand it is worth noting that substantial problems can affect this small breeding population, such as the loss of genetic variation and demographic stochasticity (Gilpin, 1991; Ryan and Siegfried, 1994). For this reason, one of the first steps in the conservation of the Egyptian vulture could be to gain an understanding of the effects of small isolated populations on the extent and pattern of genetic variations by documenting a number of basic population genetic parameters, such as level of inbreeding depression. As suggested by Caughley (1994), there is frequently a lack of information on many of these factors, especially for critically endangered species: for "fear" of interference with and manipulation of the last 
few individuals, people involved in conservation and management run the risk of themselves becoming responsible for local extinction.

\section{Acknowledgements}

We would like to thank all the volunteers of the ALTURA (the Italian Association for the Protection of Raptors and their Habitats), in particular its President, S. Allavena, and A. Sigismondi, N. Cillo, F. Quaranta, M. Salerno, L. Quaranta, E. Muscianese, as well as the volunteers of the CIPR (Italian Committee for the Protection of Raptors) and P. Cortone (who contributed to the development of the surveys in Calabria), P. Rocca and M. Visceglie, all for their invaluable help in the field. Particular thanks to the WWF Tuscany, G. Ceccolini, R. Nardi and S. Scoccianti for their precious work in the creation of the Egyptian vulture Captive Breeding Centre, and for the important results they have obtained. We thank J.A. Donazar, M. Ferrer, F. Hiraldo, S. Saraceni, F. Sergio, S. Velasco and two anonymous referees for the useful comments on a first draft of the paper. The Italian survey and the creation of the artificial feeding point were supported by partial financial help from the WWF Italy.

\section{References}

Abuladze, A., Shergalin, J., 1998. The Egyptian vulture Neophron percnopterus in the former USSR. Holarctic Birds of Prey, ADENEX-World Working Group on Birds of Prey and Owls, 183-195.

Baumgart, W., 1991. Uber die Geier Bulgariens. A. Der Schmutzgeier (Neophron percnopterus). Beitrage Vogelkunde 37, 1-48.

Bergier, P., 1985. La reproduction du vautour percnoptere Neophron percnopterus en Provence (S.E. France) de 1979 a 1983. Bulletin World Working Group on Birds of Prey and Owls 2, 77-78.

Bergier, P., Cheylan, G., 1980. Statut, succes de reproduction et alimentation du vautour percnoptere (Neophron percnopterus) en France mediterraneenne. Alauda 48, 75-97.

Bijleveld, M., 1974. Birds of Prey in Europe. Macmillan, London.

Bologna, G., 1976. Annotazioni sulla situazione attuale del capovaccaio o avvoltoio degli egizi in Italia. S.O.S. Fauna. Animali in pericolo in Italia. W.W.W., Camerino, Italia (pp. 43-65).

Braillon, B., 1979. Le percnoptere dans les Pyrenees francaises. Cahiers Universite Pau Pays de l'Adour 1, 319-329.

Braillon, B., 1987. La nidification du vautour percnoptere Neophron percnopterus sur le versant Nord des Pyrenees, un suivi d'ensemble commence il y a 27 ans. Acta Biologica Montana 7, 101-113.

Brown, D., 1975. A test of randomness of nest spacing. Wildfowl 26, 102-103.

Canut, J., Garcia-Ferre, D., Marco, J., Ceballos, O., 1988. Le percnoptere d'Egypte. Acta Biologica Montana 8, 105-118.

Carlon, J., 1992. Breeding phenology of the Egyptian vulture. World Working Group on Birds of Prey and Owls, Newsletter 16/17, 12-13.

Carrillo, J., Delgado, G., 1991. Threats to and conservationist aspects of birds of prey in the Canary Islands. Birds of Prey Bulletin 4, 25-32.

Caughley, G., 1994. Directions in conservation biology. Journal of Animal Ecology 63, 215-244.

Ceballos, O., Donazar, J.A., 1988. Actividad, uso del espacio y cuidado parental en una pareja de alimoches (Neophron percnopterus) durante el periodo de dependencia de los pollos. Ecologia 2, 275-291.

Cortone, P., Liberatori, F., 1989. Aggiornamento sulla situazione del Capovaccaio, Neophron percnopterus, nell'Italia peninsulare. Rivista italiana Ornitologia 59, 49-59.

Donazar, J.A., 1993. Los buitres ibericos. Biologia y conservacion. Ed. Reyero, Madrid.

Donazar, J.A., 1994. Egyptian vulture Neophron percnopterus. In: Tucker, G.M., Heat, M.F. (Eds.), Birds in Europe: Their Conservation Status. BirdLife Conservation Series No. 3. BirdLife International, Cambridge, pp. 154-155.

Donazar, J.A., Ceballos, O., 1988. Alimentacion y tasas reproductoras del alimoche (Neophron percnopterus) en Navarra. Ardeola 35, 3-14.

Donazar, J.A., Ceballos, O., Leon, C.F., 1989. Factors influencing the distribution and abundance of seven cliff-nesting raptors: a multivariate study. Raptors in the Modern World, World Working Group on Birds of Prey and Owls, Berlin, 545-549.

Elosegi, I., 1989. Vautour fauve (Gyps fulvus), Gypaete barbu (Gypaetus barbatus), Percnoptere d'Egypte (Neophron percnopterus): synthese bibliographique et recherches. Acta Biologica Montana 3. Pau.

Fretwell, S.D., Lucas, J.H.J., 1970. On territorial behaviour and other factors influencing habitat distribution in birds. Acta Biotheoretica $19,16-36$.

Frier, J., 1978. Faune ardechoise menacee: le vautour percnoptere Neophron percnopterus. Nature 4, 17-30.

Gallardo, M., Penteriani, V., 1999. Intervention plan on the Egyptian Vulture Neophron percnopterus in France. Bibliographic synthesis and Conservation Implications. Direction de la nature et des paysages, Ministere de l'Environnement (in French).

Gallardo, M., Astruy, J.C., Cochet, G., Seriot, J., Neri, F., Torre, J., Thibault, J.C., 1987. Gestion des populations de grands rapaces. Revue d'Ecologie (Terre et Vie) 4, 241-252.

Garzon, J., 1977. Birds of prey in Spain, the present situation. Proceedings World Conference Birds of Prey, Vienne, 159-170.

Gilpin, M., 1991. The genetic effective size of a metapopulation. Biological Journal of the Linnean Society 42, 165-175.

Grubac, R.B., 1989. The Egyptian vulture Neophron percnopterus in Macedonia. Raptors in the Modern World, World Working Group on Birds of Prey and Owls, Berlin, 331-333.

ISTAT., 1991. Caratteristiche strutturali delle aziende agricole. Fascicoli Provinciali. $4^{\circ}$ Censimento Generale dell'Agricoltura, Italy.

Levy, N., 1990. Biology, population dynamics and ecology of the Egyptian vultures, Neophron percnopterus, in Israel. MSc thesis, TelAviv University.

Levy, N., 1991. Feedings habits and food composition of the Egyptian vulture Neophron percnopterus in Israel. Israel Journal of Zoology 37, 159-190.

Levy, N., Mendelssohn, H., 1989. Egyptian vultures: feeding behavior. Israel Land and Nature 14, 126-131.

Liberatori, F., 1993. Capovaccaio, Neophron percnopterus. Atlante degli Uccelli nidificanti in Italia. Supplementi Ricerche Biologi Selvaggina $X X, 75$.

Liberatori, F., Cortone, P., 1991. Emergenza Capovaccaio (Neophron percnopterus): proposte per un piano urgente di tutela e ripopolamento. Supplementi Ricerche Biologi Selvaggina XVII, 413-416.

Liberatori, F., Cortone, P., 1993. Updated status of vultures in Italy. Vulture News 26, 7-14.

Liberatori, F., Massa, B., 1992. Capovaccaio Neophron percnopterus. In: Brichetti, P., De Franceschi, P., Baccetti, N. (Eds.), Fauna d'Italia, Aves. I. Gaviidae-Phasianidae. Edagricole, Bologna, pp. 488-493.

Marco, J., Garcia, D., 1981. Situation actuelle des populations de necrophages (Gyps fulvus, Gypaëtus barbatus et Neophron percnopterus) en Catalogne. Rapaces mediterraneens, 66-69.

McCullough, D.R. (Ed.), 1996. Metapopulations and Wildlife Conservation. Island Press, Washington, DC. 
Meretsky, V.J., 1995. Foraging ecology of Egyptian vultures in the Negev Desert, Israel. Dissertation, University of Arizona, Tucson, AZ.

Meretsky, V.J., Mannan, R.W., 1999. Supplemental feeding regimes for Egyptian vultures in the Negev Desert, Israel. Journal of Wildlife Management 63, 107-115.

Mundy, P., Butchart, D., Ledger, J., Piper, S., 1992. The Vultures of Africa. Academic Press, London.

Muntaner, J., 1985. The status of diurnal birds of prey in Catalonia, north-eastern Spain. I.C.B.P. Technical Publication 5, 29-43.

Newton, I., 1979. Population Ecology of Raptors. T \& A D Poyser, Hertfordshire.

Newton, I., 1989. Lifetime Reproduction in Birds. Academic Press, London.

Perea, J.L., Morales, M., Velasco, J., 1991a. Espana posee la principal poblacion de alimoches de Europa. Quercus 68, 15-22.

Perea, J.L., Morales, M., Velasco, J., 1991b. El alimoche (Neophron percnopterus) en Espana. Poblacion, distribucion, problematica y conservacion. ICONA, Collecion Tecnica, Madrid, Espagne.

Ryan, P.G., Siegfried, W.R., 1994. The viability of small populations of birds: an empirical investigation of vulnerability. In: Remmert, H. (Ed.), Minimum Animal Populations. Springer-Verlag, Berlin, pp. 3-22.

Sergio, F., Bogliani, G., 1999. Eurasian hobby density, nest area occupancy, diet, and productivity in relation to intensive agriculture. Condor 101, 806-817.
Simeon, D., Cheylan, G., 1985. Conservation strategies for raptors in the south of France. Bulletin World Working Group on Birds of Prey and Owls 2, 113-116.

Sokal, R.R., Rohlf, F.J., 1995. Biometry, the Principles and Practice of Statistics in Biological Research, 3rd Edition. Freeman, New York.

Steenhof, K., 1987. Assessing raptor reproductive success and productivity. In: Giron Pendleton, B.A., Millsap, B.A., Cline, K.W., Bird, D.M. (Eds.), Raptor Management Techniques Manual. National Wildlife Federation 10, Washington DC, pp. 157-170.

Terrasse, J.-F., 1985. The effects of artificial feeding on griffon, bearded and Egyptian vultures in the Pyrenees. I.C.B.P. Technical Publication 5, 429-430.

Tico, J., Tico, J.R., 1984. Situacio actual de la poblacio de rapinyaires diurns a Catalunya. Rapinyaires Mediterranis 2, 210-217.

Vasconcelos, M., 1987. Le dynamique des populations de necrophages (Gyps fulvus et Neophron percnopterus) au fleuve Tejo International. Supplementi Ricerche Biologi Selvaggina 12, 287-294.

Vlachos, C.G., Papageorgiou, N.K., Bakaloudis, D.E., 1998. Effects of the feeding station establishment on the Egyptian vulture Neophron percnopterus in Dadia Forest, North Eastern Greece. Holarctic Birds of Prey, ADENEX- World Working Group on Birds of Prey and Owls, 197-207. 